\title{
Response of Sugar Beet Yield to Deficit Irrigation under Drip Irrigation System
}

\author{
G. Abdel-Nasser ${ }^{1}$, Kh. T. BenAbdalla ${ }^{2}$, A. M. Osman ${ }^{3}$, \\ I. M. A. Goher ${ }^{4}$, and K. M. Agami ${ }^{5}$
}

\author{
${ }^{1}$ Soil and Agricultural Chemistry Dept., Faculty of Agriculture (Saba Bacha)-Alexandria \\ University, \\ ${ }^{2}$ Faculty of Agriculture, Soil and Water Dept., Azzaytuna University, Tripoli, Libya \\ ${ }^{3}$ Water Requirements and Field Irrigation Dept., Nubaria Agricultural Research Station, \\ Agricultural Research Center, Cairo, Egypt \\ ${ }^{4}$ Head of Nubariya Sugar Crop Research Unit, Sugar Crops Research \\ Institute, Agricultural Research Center, Egypt \\ ${ }^{5}$ Department of Agronomy and Agricultural Practices, Sugar Crops Research Institute, \\ Agricultural Research Center, Egypt
}

Corresponding author: G. Abdel-Nasser - e-mail: nasserga@gmail.com

\begin{abstract}
A field experiment of drip-irrigated sugar beet (Beta vulgaris, L.) was conducted at the research field of the Nubaria Agricultural Research Station, Egypt at $30^{\circ} 54^{\prime}$ $21^{\prime \prime} \mathrm{N}, 29^{\circ} 52^{\prime} 15^{\prime \prime} \mathrm{E}$ and $11.0 \mathrm{~m}$ altitude above mean sea level during 2011/2012 growing season. The aim of the present study was to evaluate the impact of deficit irrigation on sugar beet productivity, and quantitative and qualitative characteristics of sugar beet root yield under drip irrigation. The sugar beet (Beta vulgaris, L) variety Gloria (polygerm) was planted on 13 October 2011. Sugar beet plants were thinned to one plant at distance of about $0.3 \mathrm{~m}$ on the rows at the $4^{\text {th }}$ week after planting. After emergence, the plots were irrigated by the drip irrigation method. The present study consisted of 5 treatments. The irrigation treatments were based on replenishment of soil water depletion according to reference evapotranspiration $\left(\mathrm{ET}_{0}\right)$. The irrigation treatments were: Irrigation at $40,60,80,100$ and $120 \%$ of $\mathrm{ET}_{0}$. Sugar beet vegetative growth, sugar beet yield and yield components, and juice quality and impurities content were determined. The results clearly indicated a significant effect of different irrigation regimes on all sugar beet growth characters except leaf area per plant and foliage water content as compared with control $\left(100 \%\right.$ of $\left.\mathrm{ET}_{0}\right)$. The results also clearly indicated a significant effect of irrigation regimes on sugar beet yield and yield components. Irrigation at $40 \%$ of $\mathrm{ET}_{0}$ gave a highest value of root length $(32.7 \mathrm{~cm})$ and root diameter $(13.0 \mathrm{~cm})$, but $60 \%$ of $\mathrm{ET}_{0}$ gave the highest values of average root fresh weight $(1500 \mathrm{~g} /$ plant $)$ and root gross yield (100.0 ton/ha). The highest value of root/top ratio (1.31) was attained at irrigation with $120 \%$ of $\mathrm{ET}_{0}$. The percent increase of root gross yield of sugar beet at $60 \%$ of $\mathrm{ET}_{0}$ was account as $49.99 \%$, for gross sugar yield was $45.66 \%$ and for white sugar yield was $44.16 \%$ over the common treatment $\left(100 \%\right.$ of $\left.\mathrm{ET}_{0}\right)$. The different irrigation regimes significantly affected the juice quality and impurities contents of sugar beet. Irrigation at 40 and $60 \%$ of $\mathrm{ET}_{0}$ gave the highest value of TSS (total soluble solids), $23.0 \%$, white sugar yield (13.71 ton/ha), gross sugar yield (16.97 ton/ha) and loss sugar yield (3.26 ton/ha) were attained at $60 \%$ of $\mathrm{ET}_{0}$. The highest values of polarity or sucrose content (17.76 \%), effective polarimetric assay of sugar $(15.46 \%)$, thick purity juice, TPJ $(90.66 \%)$, white sugar content $(14.94 \%)$ and juice purity $(84.13 \%)$ were attained at $60 \%$ of $\mathrm{ET}_{0}$. The increase in sugar yield was due to both increase in sugar content and root yield in which sugar yield was adversely affected by water deficit. Increasing the impurities in the root of stressed plants decreased extraction of white sugar. So, deficit irrigation improved sugar beet quality by reducing these impurities. The findings in this study strongly recommend that up to $60 \%$ deficit irrigation of sugar beet would be advantage if the farmers target is to maximize root and white sugar yield. But if the target is to put more area into production under limited water supply, irrigation at $40 \%$ of reference evapotranspiration in sugar beet may be feasible.
\end{abstract}


Keywords: sugar beet, irrigation deficit, limited irrigation, WUE, water productivity, sugar yield

\section{INTRODUCTION}

Sugar beet is insensitive to water stress (Salter and Goode, 1967) and tolerates moderate soil water stress (Hills et al., 1990). Sugar beet is adapted to a wide range of climatic conditions and soil salinity (Katerji et al., 1997). On the other hand, controlled deficit irrigation pattern has been shown as an efficient tool for further research (Pidgeon et al., 2001; Tognetti et al., 2003; Shrestha et al., 2010). Kirda (2002) suggested low irrigation as the cause of higher sucrose concentration in sugar beet. Karimi and Naderi (2008) stated the positive role of late-season water and water deficit stresses in sugar yield rise, while Mirzaee and Rezvani (2007) found that drought stress adversely affected qualitative traits of sugar beet in Hamedān, Iran and revealed that irrigation withdrawal during late growing season resulted in the loss of qualitative characteristics of sugar beet including gross sugar percentage and extraction efficiency. Lategrowing season moisture stress increases the impurities of sugar beet roots such as $\mathrm{K}$ and $\mathrm{Na}$ and consequently, significantly decreases sugar extraction efficiency and increases molasses percentage.

Until today, much research on the effects of deficit irrigation water on quantity and quality of sugar beet have been performed in during the last few years by different researchers (Jahadakbar et al., 2003; Mahmoodi et al., 2008; Hoffmann et al., 2009; Hassanli et al., 2010). Additionally, much research needs to be conducted on sugar beet producing regions where sugar beet grows with a shortage of water resources during the growing period.

The aim of the present study is to evaluate the effect of deficit irrigation on sugar beet productivity, water use efficiency, and quantitative and qualitative characteristics of sugar beet root yield under drip irrigation.

\section{MATERIALS AND METHODS}

\section{Field experiment}

The field experiment using drip-irrigated sugar beet (Beta vulgaris, L.) was conducted at the research field of the Nubaria Agricultural Research Station, Egypt (at 30 54' 21" N, 29 $52^{\circ} 15^{\prime \prime} \mathrm{E}$ and $11.0 \mathrm{~m}$ altitude above mean sea level) during 2011/2012 growing season. Climate in this region is semi-arid with total annual precipitation of $123.0 \mathrm{~mm}$. The experimental site has mild rainy winters and hot and dry summer. The meteorological data were obtained from Central Laboratory for Agricultural Climate (CLAC), Ministry of Agriculture, Egypt. Some meteorological data for the experimental site are given in Table (1).

\section{Soil of the experimental site}

Soil samples were collected from each treatment to form a composite sample representing the soil of the experimental site for both surface $(0-30 \mathrm{~cm})$ and subsurface $(30-60 \mathrm{~cm})$. Some physical and chemical properties of the experimental field soil are presented in Table (2). The soil properties were performed according to the procedures outlined in Carter and Gregorich (2008). 


\section{Land preparation}

The experimental site was subjected to leveling possess and then the drip irrigation network was established.

A drip irrigation system was designed for the experiment. Irrigation water was taken by a centrifugal pump, powered by a $3.88 \mathrm{~kW}$ engine from a well near the experimental site. The control unit consisted of a screen filter with $10 \mathrm{I}$ $\mathrm{s}^{-1}$ capacity, control valves and manometers mounted on the inlet and outlet of each unit. Distribution lines consisted of PVC pipe manifolds for each plot. The diameter of the polyethylene laterals were $16 \mathrm{~mm}$ and each lateral irrigated one plant row. The inline emitter discharge rate was $4 \mathrm{I} \mathrm{h}^{-1}$ at $100 \mathrm{kPa}$ operating pressure. The actual emitter discharge rate was calibrated before starting the experiment. The drip network calibration was performed and the actual rate of emitter was $3.43 \mathrm{I} \mathrm{h}^{-1}$.

\section{Sugar beet cultivation}

The sugar beet (Beta vulgaris, L) variety Gloria (polygerm) was planted on $13^{\text {th }}$ October 2011 (Days of year $=286$ ). Sugar beet plants were thinned to one plant at distance of about $0.3 \mathrm{~m}$ on the rows at the $4^{\text {th }}$ week after planting. After emergence, the plots were irrigated by the drip irrigation method.

Soil of the experimental site was fertilized using $150 \mathrm{~kg} \mathrm{ha}^{-1}$ as calcium superphosphate $\left(15.5 \% \quad \mathrm{P}_{2} \mathrm{O}_{5}\right)$ during land preparation and $150 \mathrm{~kg} \mathrm{ha}^{-1}$ as ammonium nitrate $(33.5 \% \mathrm{~N})$ at two equal doses, one after sowing and the second after one month later. $120 \mathrm{~kg} \mathrm{ha}^{-1}$ as potassium sulfate $\left(48 \% \mathrm{~K}_{2} \mathrm{O}\right)$ was added at two equal doses, one after sowing and the second after one month later.

\section{Irrigation regime}

The present study consisted of 5 treatments. The irrigation treatments were based on replenishment of soil water depletion according to reference evapotranspiration $\left(\mathrm{ET}_{0}\right)$. The irrigation treatments were: Irrigation at $40 \%$ of $\mathrm{ET}_{0}$, Irrigation at $60 \%$ of $\mathrm{ET}_{0}$, Irrigation at $80 \%$ of $\mathrm{ET}_{0}$, Irrigation at $100 \%$ of $\mathrm{ET}_{0}$, and Irrigation at $120 \%$ of $\mathrm{ET}_{0}$.

Treatments layout were conducted to a randomized complete block design with three replications. There was $1.0 \mathrm{~m}$ separation between each plot in order to minimize lateral water movement among treatments. Each experimental plot was $25.0 \mathrm{~m}$ long and had a total area of $25.0 \mathrm{~m}^{2}(1.0 \mathrm{~m}$ row wide with two side cultivation). Table (3) shows the chemical analysis of water used for irrigation. Chemical analysis of water was done according the methods outlined in Eaton and Franson (2005).

Soil water content was measured by sampling a soil from each row with soil tube $0.025 \mathrm{~m}$ diameter at two depths i.e. $0-30$ and $30-60 \mathrm{~cm}$ prior irrigation and determined by gravimetric method. Soil water tension was monitored prior each irrigation and after irrigation at surface and subsurface depths through electronic pressure transducer (electronic tensimeter).

Daily rainfall was recorded in the climate station near the experimental site $\left(30^{\circ} 54^{\prime} 21^{\prime \prime} \mathrm{N}\right.$ latitude, $29^{\circ} 52^{\prime} 16^{\prime \prime} \mathrm{E}$ longitude and $10 \mathrm{~m}$ altitude above mean sea level). The total rainfall within the growing season was $93.8 \mathrm{~mm}$. All climatic parameters were recorded from Automatic Weather Station established 
in the Nubaria Agricultural Research Station nearby the experimental site $(5 \mathrm{~km}$ distance), Table (1).

\section{Sugar Beet Characteristics}

\section{Vegetative growth}

One month before harvest, top of sugar beet was sampled to determine the vegetative characters such as: number of leaves/plant, leaf area/plant $\left(\mathrm{cm}^{2}\right)$, top fresh weight $(\mathrm{g})$, top water content (\%), total chlorophyll (mg $100 \mathrm{~g}^{-1}$ plant), dry matter content (\%).

\section{Sugar beet yield and yield components}

At harvest time (192 days after sowing, Days of year=112), the yield was collected from the each replicate and then computed on the basis of one hectare and other character were determined i.e. Mean root fresh weight (RFW, $\mathrm{kg} \mathrm{ha}^{-1}$ ), Root length (RL, cm ), Root diameter (RD, cm ), Total Soluble Solids (TSS,\%), Root water content (RWC,\%), Root dry matter content (RDM,\%), Root/top ratio.

\section{Juice quality and impurities content}

Yield data were collected at harvest on $22^{\text {th }}$ April 2012 (with growing season about 192 days long). Sugar beet plants of each plot were up-rooted, topped, cleaned and weighed to determine root yield $(\mathrm{kg} / \mathrm{ha})$. Whereas, sugar yield per hectare was estimated after taking subsamples from each plot (about 10 roots) as fully cleaned roots and sent to Nile Sugar Company Lab and Sugar Crops Institute at Nubaria to determine physiological and chemical characters.

Sucrose accumulation ( $\mathrm{t} \mathrm{ha}^{-1}$ ) and yield of sugar beets per hectare were estimated on three replicate plants per irrigation regime. Preparation of thick juice from sugar beet sub-samples (each sample was $10 \mathrm{~kg}$ of beet) on a laboratory scale, followed the method of Wieninger and Kubadinow (1971), to establish the internal quality of sugar beet.

Alkalinity of sugar (Ak) was estimated as:

$$
\mathrm{AK}=\frac{\mathrm{K}+\mathrm{Na}}{\alpha \mathrm{N}} \text { meq } 100 \mathrm{~g}^{-1}
$$

Where:

$\mathrm{K}$ and $\mathrm{Na}$ are alkali elements (determined by flame photometry) and $\alpha$-amino $\mathrm{N}$ is estimated according to the procedure of Sugar Company by auto analyzer described by Bhador et al. (2010).

Effective polarimetric assay of sugar $\left({ }^{\circ} S_{e}, \%\right)$, measuring the sucrose content of molasses, was corrected as polarimetry without corrections $\left({ }^{\circ} \mathbf{S}_{\mathbf{t}}, \%\right)$ minus percent of sucrose to molasses $\left({ }^{\circ} S_{m}, \%\right)$, the latter calculated from the equation (Pollach et al., 1996):

$$
\begin{aligned}
& { }^{\circ} \mathrm{S}_{\mathrm{m}}=0.3492(\mathrm{~K}+\mathrm{Na}) \text { if } \mathrm{AK}>=1.8 \\
& { }^{\circ} \mathrm{S}_{\mathrm{m}}=0.6285(\alpha \mathrm{N}) \text { if } \mathrm{AK}<1.8
\end{aligned}
$$


Table (1). Daily maximum, minimum and average temperature, wind speed, solar radiation and average daily reference evapotranspiration $\left(\mathrm{ET}_{0}\right)$ for the experimental site during the experimental period

\begin{tabular}{|c|c|c|c|c|c|c|c|}
\hline $\begin{array}{l}\text { Growing } \\
\text { Months }\end{array}$ & $\begin{array}{c}\text { Average } \\
\text { minimum } \\
\text { daily } \\
\text { temperature } \\
\mathrm{T}_{\min }\left({ }^{\circ} \mathrm{C}\right) \\
\end{array}$ & $\begin{array}{c}\text { Average } \\
\text { maximum } \\
\text { daily } \\
\text { temperature } \\
\mathrm{T}_{\max }\left({ }^{\circ} \mathrm{C}\right)\end{array}$ & $\begin{array}{c}\text { Average daily } \\
\text { temperature } \\
\mathrm{T}_{\mathrm{av}}\left({ }^{\circ} \mathrm{C}\right)\end{array}$ & $\begin{array}{l}\text { Average } \\
\text { daily wind } \\
\text { speed } \\
\mathrm{U}_{2}\left(\mathrm{~m} \cdot \mathrm{s}^{-1}\right)\end{array}$ & $\begin{array}{c}\text { Average } \\
\text { precipitation } \\
\mathrm{P}_{\mathrm{e}} \mathrm{mm}^{-1} \text { month }^{-1}\end{array}$ & $\begin{array}{l}\text { Average daily } \\
\text { solar radiation } \\
\left(\mathrm{MJ} \cdot \mathrm{m}^{-2} \cdot \text { day }^{-1}\right)\end{array}$ & $\begin{array}{c}\text { Daily reference } \\
\text { evapotranspiration } \\
\left(m \mathrm{~m} . \text { day }^{-1}\right)\end{array}$ \\
\hline October, 2011 & 15.75 & 28.21 & 21.37 & 2.15 & 3.00 & 13.75 & 2.40 \\
\hline November, 2011 & 10.91 & 22.26 & 15.87 & 2.11 & 35.00 & 9.17 & 1.42 \\
\hline December, 2011 & 8.36 & 20.16 & 13.31 & 1.93 & 4.40 & 7.39 & 1.06 \\
\hline January, 2012 & 7.42 & 17.01 & 11.61 & 2.68 & 48.00 & 7.99 & 1.27 \\
\hline February, 2012 & 8.5 & 18.2 & 12.9 & 2.57 & 0.60 & 10.90 & 1.85 \\
\hline March, 2012 & 8.38 & 21.95 & 14.65 & 2.26 & 2.80 & 17.14 & 2.58 \\
\hline April, 2012 & 12.48 & 27.33 & 19.02 & 2.11 & 0.40 & 17.93 & 3.26 \\
\hline
\end{tabular}

Source of data is Central Laboratory for Agricultural Climate (CLAC), Ministry of Agriculture, Egypt 
Table (2). Some soil physical and chemical properties of experimental site used in the present study

\begin{tabular}{|c|c|c|c|}
\hline Soil parameters & $\begin{array}{l}0-30 \mathrm{~cm} \\
\text { depth }\end{array}$ & $\begin{array}{c}30-60 \mathrm{~cm} \\
\text { depth }\end{array}$ & Unit \\
\hline \multicolumn{4}{|l|}{ Particle size distribution } \\
\hline Sand & 64.58 & 67.75 & $\%$ \\
\hline Silt & 18.02 & 17.60 & $\%$ \\
\hline Clay & 17.33 & 15.58 & $\%$ \\
\hline Textural class & $\begin{array}{l}\text { Sandy } \\
\text { loam }\end{array}$ & $\begin{array}{l}\text { Sandy } \\
\text { loam }\end{array}$ & - \\
\hline Soil bulk density & 1.47 & 1.49 & $\mathrm{Mg} / \mathrm{m}^{3}$ \\
\hline Soil moisture content at field capacity & 25.85 & 25.50 & $\%$ \\
\hline $\begin{array}{l}\text { Soil moisture content at permanent wilting } \\
\text { point }\end{array}$ & 7.48 & 7.38 & $\%$ \\
\hline Plant available water content & 18.37 & 18.12 & $\%$ \\
\hline Organic matter content & 0.73 & 0.29 & $\%$ \\
\hline Total calcium carbonate & 24.10 & 25.81 & $\%$ \\
\hline $\begin{array}{l}\text { Electrical Conductivity }\left(\mathrm{EC}_{\mathrm{sw}}\right),(1: 1 \text {, soil: } \\
\text { water extract) } \mathrm{dS} / \mathrm{m}\end{array}$ & 7.27 & 7.43 & $\mathrm{dS} / \mathrm{m}$ \\
\hline pH (1:1, soil : water suspension) & 7.11 & 7.24 & - \\
\hline \multicolumn{4}{|l|}{ Water Soluble Cations: } \\
\hline 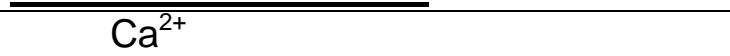 & 7.74 & 7.10 & $\mathrm{meq} / \mathrm{l}$ \\
\hline $\mathrm{Mg}^{2+}$ & 9.40 & 7.50 & $\mathrm{meq} / \mathrm{l}$ \\
\hline $\mathrm{Na}^{+}$ & 59.92 & 51.23 & $\mathrm{meq} / \mathrm{l}$ \\
\hline $\mathrm{K}^{+}$ & 2.15 & 1.75 & $\mathrm{meq} / \mathrm{l}$ \\
\hline \multicolumn{4}{|l|}{ Water Soluble Anions: } \\
\hline $\mathrm{CO}_{3}{ }_{3}$ & trace & trace & $\mathrm{meq} / \mathrm{l}$ \\
\hline $\mathrm{HCO}^{-3}$ & 4.50 & 3.64 & $\mathrm{meq} / \mathrm{l}$ \\
\hline $\mathrm{Cl}^{-}$ & 29.90 & 25.60 & meq/l \\
\hline $\mathrm{SO}_{4}$ & 44.83 & 38.40 & $\mathrm{meq} / \mathrm{l}$ \\
\hline \multicolumn{4}{|l|}{ Available nutrients: } \\
\hline Nitrogen $(\mathrm{N})$ & 41.6 & 28.3 & $\mathrm{mg} / \mathrm{kg}$ \\
\hline Phosphorus (P) & 32.1 & 37.2 & $\mathrm{mg} / \mathrm{kg}$ \\
\hline Potassium (K) & 185.2 & 192.7 & $\mathrm{mg} / \mathrm{kg}$ \\
\hline Iron $(\mathrm{Fe})$ & 0.50 & 0.75 & $\mathrm{mg} / \mathrm{kg}$ \\
\hline Manganese (Mn) & 3.00 & 3.49 & $\mathrm{mg} / \mathrm{kg}$ \\
\hline Copper (Cu) & 0.74 & 0.71 & $\mathrm{mg} / \mathrm{kg}$ \\
\hline Zinc (Zn) & 0.25 & 0.30 & $\mathrm{mg} / \mathrm{kg}$ \\
\hline Boron (B) & 0.57 & 0.34 & $\mathrm{mg} / \mathrm{kg}$ \\
\hline
\end{tabular}


Table (3). Chemical analysis of water used for irrigation

\begin{tabular}{|c|c|c|}
\hline Parameters & Value & Unit \\
\hline $\mathrm{pH}$ & 7.3 & - \\
\hline $\mathrm{EC}_{\mathrm{iw}}$ & 2.70 & $\mathrm{dS} / \mathrm{m}$ \\
\hline \multicolumn{3}{|c|}{ Water Soluble cations: } \\
\hline $\mathrm{Ca}^{+2}$ & 6.90 & $\mathrm{meq} / \mathrm{l}$ \\
\hline $\mathrm{Mg}^{+2}$ & $10 \quad .80$ & $\mathrm{meq} / \mathrm{l}$ \\
\hline $\mathrm{Na}^{+}$ & 8.96 & $\mathrm{meq} / \mathrm{l}$ \\
\hline $\mathrm{K}^{+}$ & 0.28 & $\mathrm{meq} / \mathrm{l}$ \\
\hline \multicolumn{3}{|c|}{ Water Soluble anions: } \\
\hline $\mathrm{CO}_{3}{ }_{3}+\mathrm{HCO}_{3}^{-}$ & 4.85 & $\mathrm{meq} / \mathrm{l}$ \\
\hline $\mathrm{Cl}^{-}$ & 7.07 & $\mathrm{meq} / \mathrm{l}$ \\
\hline $\mathrm{SO}^{=}{ }_{4}$ & 15.05 & $\mathrm{meq} / \mathrm{l}$ \\
\hline B & 1.97 & $\mathrm{mg} / \mathrm{l}$ \\
\hline$P$ & 2.62 & $\mathrm{mg} / \mathrm{l}$ \\
\hline
\end{tabular}

According to Pollach et al. (1996), polarimetric assay of sugar measures the sucrose content of molasses sometimes more exactly than value corrected for raffinose.

Thick purity juice (TPJ \% $=$ meq $100 \mathrm{~g}^{-1}$ ) was expressed as:

$\mathrm{TPJ}=99.36-0.1427(\mathrm{~K}+\mathrm{Na}+\alpha \mathrm{N}) \times\left(100 /{ }^{\circ} \mathrm{S}_{\mathrm{e}}\right)$

${ }^{\circ} S_{e}={ }^{\circ} S_{t}-{ }^{\circ} S_{m}$

Sucrose \% (Pol,\%): Juice sugar content of each treatment was estimated in fresh samples of sugar beet root by using Saccharometer according to the method described by A.O.A.C. (Ahadi and Sobhani, 2005).

Total soluble solids (TSS), \%

Recoverable sugar yield ( $\mathrm{kg} / \mathrm{ha}$ ) was deduced as described by Mohamed (2002), applying the following formulae:

Recoverable sugar yield $\left(\mathrm{kg} \mathrm{ha}^{-1}\right)=$ roots yield $\left(\mathrm{kg} \mathrm{ha}^{-1}\right) \times$ recoverable sugar percent (\%)

Recoverable sugar percent (\%) was deduced according to Harvey and Dutton (1993) as:

Corrected sugar content(ZB), $\%=\operatorname{Pol}(\%)-(0.343(\mathrm{~K}+\mathrm{Na})+0.094 \alpha \mathrm{N}+0.29)$

Where: Pol. \%( Sucrose \%), and $\mathrm{K}, \mathrm{Na}$, and $\alpha$ - amino-N were determined as me $100 \mathrm{~g}^{-1}$ beet.

Gross sugar yield, GSY $\left(\mathrm{kg} \mathrm{ha}^{-1}\right)=$ root yield $\left(\mathrm{kg} \mathrm{ha}^{-1}\right) \times$ gross sugar percentage

White sugar yield, WSY $\left(\mathrm{kg} \mathrm{ha}^{-1}\right)=$ root yield $\left(\mathrm{kg} \mathrm{ha}^{-1}\right) \times$ white sugar percentage

Losses sugar yield, LSY $\left(\mathrm{kg} \mathrm{ha}^{-1}\right)=$ root yield $\left(\mathrm{kg} \mathrm{ha}^{-1}\right) \times$ loss sugar percentage

Loss sugar content, $\%=$ Gross sugar content (\%) - white sugar content (\%) 
Juice purity percentage calculated as:

Juice purity, Qz $(\%)=\mathrm{ZB} \times 100 / \mathrm{Pol}$.

\section{Statistical Analysis}

All collected data for sugar beet yield and quality were subjected to analysis of variance (ANOVA) according to Snedecor and Cochran (1991). The mean values were compared according to least significant difference Test (LSD test), Williams and Abdi (2010). All statistical analyses were performed using analysis of variance technique of "Statistix 8" computer software package (Statistix, 2003).

\section{RESULTS AND DISCUSSION}

\section{Sugar beet growth characters}

The results presented in Table (4) show the response of sugar beet growth characters to different irrigation regimes. The results clearly indicated a significant effect of different irrigation regimes on all sugar beet growth characters except leaf area per plant and foliage water content as compared with control $\left(100 \%\right.$ of $\left.\mathrm{ET}_{0}\right)$. Irrigation regime at $100 \% \mathrm{ET}_{0}$ gave the highest values of no. of leaves per plant (42.3), leaf area per plant $\left(6205.7 \mathrm{~cm}^{2} /\right.$ plant $)$ and total chlorophyll content(49.73 $\mathrm{mg} / 100 \mathrm{~g}$ leaf fresh weight), but the highest values of foliage fresh weight (1517.7 $\mathrm{g} /$ plant) and top yield (101.1 ton/ha) were attained at $60 \%$ of $\mathrm{ET}_{0}$. The percent increase in top yield of sugar beet at $60 \%$ of $\mathrm{ET}_{0}$ was account as $16.50 \%$ over the common treatment $\left(100 \%\right.$ of $\left.\mathrm{ET}_{0}\right)$.

Table (4). Growth characters of sugar beet as affected by irrigation regimes

\begin{tabular}{ccccccc}
\hline $\begin{array}{c}\text { Irrigation } \\
\text { regime } \\
(\% \text { of }\end{array}$ & $\begin{array}{c}\text { Number of } \\
\text { leaves/plant }\end{array}$ & $\begin{array}{c}\text { Leaf } \\
\text { area/plant } \\
\left(\mathrm{cm}^{2}\right)\end{array}$ & $\begin{array}{c}\text { Foliage } \\
\text { fresh } \\
\text { weight } \\
\text { (g/plant) }\end{array}$ & $\begin{array}{c}\text { Top } \\
\text { Yield } \\
\text { ton/ha }\end{array}$ & $\begin{array}{c}\text { Top } \\
\text { water } \\
\text { content } \\
(\%)\end{array}$ & $\begin{array}{c}\text { Total } \\
\text { chlorophyll } \\
(\mathrm{mg} / 100 \mathrm{~g} \\
\text { leaf })\end{array}$ \\
\hline 40 & $33.0 \mathrm{~B}$ & 5006.0 & $1093.4 \mathrm{~B}$ & $72.8 \mathrm{~B}$ & $92.84 \mathrm{~A}$ & $21.70 \mathrm{E}$ \\
60 & $40.7 \mathrm{AB}$ & 5200.7 & $1517.7 \mathrm{~A}$ & $101.1 \mathrm{~A}$ & $93.20 \mathrm{~A}$ & $37.18 \mathrm{C}$ \\
80 & $39.0 \mathrm{AB}$ & 5177.7 & $1218.9 \mathrm{~B}$ & $81.2 \mathrm{~B}$ & $94.70 \mathrm{~A}$ & $45.59 \mathrm{~B}$ \\
100 & $42.3 \mathrm{~A}$ & 6205.7 & $1302.7 \mathrm{~B}$ & $86.7 \mathrm{AB}$ & $94.95 \mathrm{~A}$ & $49.73 \mathrm{~A}$ \\
120 & $35.7 \mathrm{AB}$ & 5056.3 & $1300.5 \mathrm{~B}$ & $86.6 \mathrm{~B}$ & $95.66 \mathrm{~A}$ & $32.91 \mathrm{D}$ \\
$\mathrm{LSD}(0.05)$ & $9.1678^{*}$ & $2937.2^{\mathrm{NS}}$ & $215.43^{*}$ & $14.35^{*}$ & $4.22^{\mathrm{NS}}$ & $3.89^{*}$ \\
\hline
\end{tabular}




\section{Yield and yield components}

Table (5) shows sugar beet yield and yield component parameters of sugar beet as influenced by irrigation regime treatments. The results clearly indicate a significant effect of irrigation regimes on sugar yield and yield components. Irrigation at $40 \%$ of $\mathrm{ET}_{0}$ gave a highest value of root length $(32.7 \mathrm{~cm})$ and root diameter $(13.0 \mathrm{~cm})$, but $60 \%$ of $\mathrm{ET}_{0}$ gave the highest values of average root fresh weight (1500 g/plant) and root gross yield (100.0 ton/ha). The highest value of root/top ratio (1.31) was attained at irrigation with $120 \%$ of $E T_{0}$. The percent increase of root gross yield of sugar beet at 60 of $\mathrm{ET}_{0}$ was account as $49.99 \%$ over the common treatment ( $100 \%$ of $\left.\mathrm{ET}_{0}\right)$.

According to the present results, to get maximum root yield of sugar beet under the present condition of Nubaria region, it might be recommended irrigation at $60 \%$ of $\mathrm{ET}_{0}$. This case of suitable soil water resulted in healthy plants, also highest foliage yield consequently higher yield could be obtained and vise versa regards the extra or less soil water availability. These results are in agreement with those of Bailey (1990) and Emara (1996).

Table (5). Sugar beet yield and yield components as affected by irrigation regimes

\begin{tabular}{ccccccc}
\hline $\begin{array}{c}\text { Irrigation } \\
\text { regime } \\
(\% \text { of ET })\end{array}$ & $\begin{array}{c}\text { Average } \\
\text { root } \\
\text { fresh } \\
\text { weight } \\
\text { (g/plant) }\end{array}$ & $\begin{array}{c}\text { Root } \\
\text { gross } \\
\text { yield } \\
\text { (ton/ha) }\end{array}$ & $\begin{array}{c}\text { Root } \\
\text { length } \\
(\mathrm{cm})\end{array}$ & $\begin{array}{c}\text { Root } \\
\text { diameter } \\
(\mathrm{cm})\end{array}$ & $\begin{array}{c}\text { Root } \\
\text { water } \\
\text { content } \\
(\%)\end{array}$ & $\begin{array}{c}\text { Root/Top } \\
\text { ratio }\end{array}$ \\
\hline 40 & $1429 \mathrm{~A}$ & $95.24 \mathrm{~A}$ & $32.7 \mathrm{~A}$ & $13.0 \mathrm{~A}$ & $40.58 \mathrm{~B}$ & $1.310 \mathrm{~A}$ \\
60 & $1500 \mathrm{~A}$ & $100.00 \mathrm{~A}$ & $30.3 \mathrm{AB}$ & $11.7 \mathrm{AB}$ & $42.26 \mathrm{~A}$ & $0.990 \mathrm{~B}$ \\
80 & $1211 \mathrm{~B}$ & $80.74 \mathrm{~B}$ & $29.0 \mathrm{~B}$ & $10.0 \mathrm{BC}$ & $44.26 \mathrm{~A}$ & $0.997 \mathrm{~B}$ \\
100 & $1000 \mathrm{C}$ & $66.67 \mathrm{C}$ & $29.7 \mathrm{AB}$ & $9.00 \mathrm{C}$ & $46.26 \mathrm{~A}$ & $0.770 \mathrm{C}$ \\
120 & $833 \mathrm{D}$ & $55.56 \mathrm{D}$ & $30.0 \mathrm{AB}$ & $8.33 \mathrm{C}$ & $47.21 \mathrm{~A}$ & $0.653 \mathrm{C}$ \\
$\mathrm{LSD}(0.05)$ & $131.15^{*}$ & $8.74^{*}$ & $3.55^{*}$ & $2.37^{*}$ & $2.60^{*}$ & $0.164^{*}$ \\
\hline
\end{tabular}

\section{Juice quality and impurities contents}

The results of juice quality and impurities content are illustrated in Table $(6-1,6-2)$. The different irrigation regimes significantly affected the juice quality and impurities contents of sugar beet. Irrigation at 40 and $60 \%$ of $\mathrm{ET}_{0}$ gave the highest value of TSS (total soluble solids), $23.0 \%$, but the highest values of $\mathrm{K}$ (6.62 meq/100g root), $\alpha$-amino $\mathrm{N}(4.39 \mathrm{meq} / 100 \mathrm{~g}$ root), white sugar yield (13.71 ton/ha), gross sugar yield(16.97 ton/ha) and loss sugar yield (3.26 ton/ha) were attained at $60 \%$ of $\mathrm{ET}_{0}$. The highest values of polarity or sucrose content (17.76 $\%)$, effective polarimetric assay of sugar (15.46\%), thick purity juice, TPJ $(90.66 \%)$, white sugar content $(14.94 \%)$ and juice purity $(84.13 \%)$ were attained at $80 \%$ of $\mathrm{ET}_{0}$. Irrigation at $120 \%$ of $\mathrm{ET}_{0}$ gave a highest value of $\mathrm{Na}$ content (1.69 meq/100g root).

The increase in sugar yield was due to both increase in sugar content and root yield in which sugar yield was adversely affected by water deficit. 
Increasing the impurities in the root of stressed plants decreased extraction of white sugar. So, deficit irrigation improved sugar beet quality by reducing these impurities.

Alkaline coefficient (AK) is considered as an indicator to determine the juice impurity. The $A c$ is affected by both the sodium + potassium $(\mathrm{Na}+\mathrm{K})$ as nominator and $\alpha$-amino-nitrogen ( $\alpha$-amino $N$ ) as dominator. So, increasing the dominator, the Ac will be decreased and vise versa. The threshold value of Ac is $1.8 \%$, the values higher than $1.8 \%$ indicated that high purity sugar beet. The chemical characteristic of sugar beet juice was mainly affected by the sugar crystallization process. There are high sucrose content associated with low contents of $\mathrm{K}, \mathrm{Na}$ and $\alpha$-amino- $\mathrm{N}$ contents. It is also important for stability of juice in the factory that the content of $\alpha$-amino $\mathrm{N}$ would be maintained low in relation to that of $\mathrm{K}$ and $\mathrm{Na}$.

The effect of irrigation water levels on $\mathrm{Na}$ content of roots was not consistent throughout the treatments. Sodium had significant variation among treatment. $\mathrm{Na}$ value ranged from $0.83 \mathrm{me} / 100 \mathrm{~g}$ root for $60 \%$ deficit irrigation to $1.69 \mathrm{meq} / 100 \mathrm{~g}$ root for $120 \%$ deficit irrigation. Several researchers (Fabeiro et al., 2003; Ober et al., 2005) reported that the effect of water deficit on $\mathrm{Na}$ content is less clear and varies between treatments. However, some studies showed that as deficit water increased, Na content decreased (Tognetti et al., 2003; Maralian et al., 2008).

Bosemark (1993) reported that the chemical characteristics of sugar beet juice were mainly affected by the sugar crystallization process. There are high sucrose content associated with low contents of $\mathrm{K}, \mathrm{Na}$ and alpha-amino- $\mathrm{N}$ and betaine contents. It is also important for stability of juice in the factory that the content of alpha-amino- $\mathrm{N}$ would be maintained low in relation to that of $\mathrm{K}$ and $\mathrm{Na}$ ions.

Sugar content was affected by irrigation regimes. Therefore, root sugar content was generally increased in response to deficit irrigation treatment. Sugar beet roots accumulated more sugar $\left(16.97 \%\right.$ under $60 \%$ of $\mathrm{ET}_{0}$ deficit irrigation than under any of the full and other deficit irrigation levels. Sucrose production from sugar beet depends on maximizing storage root growth over along growing season. It is necessary to apply a suitable irrigation program together with appropriate agricultural measures for taking a high sugar rate accumulation in the sugar beet production (Ucan and Gencoglan, 2004). The increase in the sucrose rate of fresh root is due to a slower accumulation of water. Excess irrigation increased sugar beet yield, but sugar rates decreased (Bilgin, 1992).

The increase in sucrose content was $1.72 \%$ at $80 \%$ of $\mathrm{ET}_{0}$ over common treatment $\left(100 \%\right.$ of $\left.\mathrm{ET}_{0}\right)$. The economical yield of sugar beet is white sugar content, white sugar yield and gross sugar yield. The corresponding increases were $4.66,44.16$ and $45.66 \%$ at $60 \%$ of $\mathrm{ET}_{0}$ over the common treatment $(100 \%$ of $\mathrm{ET}_{0}$ ), respectively.

Table (6-1). Juice quality and impurities contents of sugar beet as affected by irrigation regimes 


\begin{tabular}{cccccccc}
\hline $\begin{array}{c}\text { Irrigation } \\
\text { regime } \\
(\% \text { of } \\
\left.\mathrm{ET}_{0}\right)\end{array}$ & $\begin{array}{c}\text { Polarity } \\
\text { or } \\
\text { sucrose } \\
\text { content } \\
(\%)\end{array}$ & $\begin{array}{c}\text { TSS } \\
(\%)\end{array}$ & $\begin{array}{c}\mathrm{K} \\
\mathrm{meq} / 100 \mathrm{~g}\end{array}$ & $\begin{array}{c}\mathrm{Na} \\
\mathrm{meq} / 100 \mathrm{~g}\end{array}$ & $\begin{array}{c}\alpha \text {-amino } \\
\mathrm{N} / 100 \mathrm{~g}\end{array}$ & $\begin{array}{c}\text { Alkaline } \\
\text { coefficient } \\
(\mathrm{AK})\end{array}$ & $\begin{array}{c}{ }^{\circ} \mathrm{S}_{\mathrm{m}} \\
(\%)\end{array}$ \\
\hline 40 & $16.63 \mathrm{AB}$ & $23.00 \mathrm{~A}$ & $5.55 \mathrm{~B}$ & $1.10 \mathrm{~B}$ & $2.38 \mathrm{D}$ & $2.79 \mathrm{~A}$ & $2.32 \mathrm{C}$ \\
60 & $16.96 \mathrm{AB}$ & $23.00 \mathrm{~A}$ & $6.62 \mathrm{~A}$ & $0.83 \mathrm{C}$ & $4.39 \mathrm{~A}$ & $1.70 \mathrm{D}$ & $2.60 \mathrm{~B}$ \\
80 & $17.76 \mathrm{~A}$ & $22.85 \mathrm{~A}$ & $5.75 \mathrm{~A}$ & $0.85 \mathrm{C}$ & $2.82 \mathrm{C}$ & $2.34 \mathrm{C}$ & $2.30 \mathrm{C}$ \\
100 & $17.46 \mathrm{AB}$ & $\begin{array}{c}22.12 \\
\mathrm{AB}\end{array}$ & $6.51 \mathrm{~A}$ & $1.18 \mathrm{~B}$ & $2.95 \mathrm{BC}$ & $2.61 \mathrm{AB}$ & 2.69 \\
120 & $16.25 \mathrm{~B}$ & $\begin{array}{c}21.67 \mathrm{~B} \\
\mathrm{men}\end{array}$ & $6.56 \mathrm{~A}$ & $1.69 \mathrm{~A}$ & $3.26 \mathrm{~B}$ & $2.53 \mathrm{BC}$ & $2.88 \mathrm{~A}$ \\
$\mathrm{LSD}(0.05)$ & $1.35^{*}$ & $1.05^{*}$ & $0.65^{*}$ & $0.18^{*}$ & $0.36^{*}$ & $0.19^{*}$ & $0.27^{*}$ \\
\hline
\end{tabular}

Table (6-2). Juice quality and impurities contents of sugar beet as affected by irrigation regimes

\begin{tabular}{c|c|c|c|c|c|c|c}
\hline $\begin{array}{c}\text { Irrigation } \\
\text { regime } \\
\left(\% \text { of } \mathrm{ET}_{0}\right)\end{array}$ & $\begin{array}{c}{ }^{\circ} \mathrm{S}_{\mathrm{e}} \\
(\%)\end{array}$ & $\begin{array}{c}\mathrm{TPJ} \\
(\%)\end{array}$ & $\begin{array}{c}\text { WSC } \\
(\%)\end{array}$ & $\begin{array}{c}\text { WSY } \\
\left(\text { ton ha }^{-1}\right)\end{array}$ & $\begin{array}{c}\text { GSY } \\
\left.\text { (ton ha }^{-1}\right)\end{array}$ & $\begin{array}{c}\text { LSY } \\
\left(\text { ton ha }^{-1}\right)\end{array}$ & $\begin{array}{c}\text { Juice } \\
\text { purity } \\
\mathrm{Qz} \\
(\%)\end{array}$ \\
\hline 40 & $14.31 \mathrm{BC}$ & $90.35 \mathrm{~A}$ & $13.84 \mathrm{BC}$ & $13.22 \mathrm{~A}$ & $15.88 \mathrm{~A}$ & $2.67 \mathrm{~B}$ & $83.20 \mathrm{AB}$ \\
60 & $14.36 \mathrm{ABC}$ & $87.59 \mathrm{C}$ & $13.70 \mathrm{BC}$ & $13.71 \mathrm{~A}$ & $16.97 \mathrm{~A}$ & $3.26 \mathrm{~A}$ & $80.79 \mathrm{CD}$ \\
80 & $15.46 \mathrm{~A}$ & $90.66 \mathrm{~A}$ & $14.94 \mathrm{~A}$ & $12.08 \mathrm{~A}$ & $14.36 \mathrm{~A}$ & $2.29 \mathrm{BC}$ & $84.13 \mathrm{~A}$ \\
100 & $14.77 \mathrm{AB}$ & $89.08 \mathrm{~B}$ & $14.26 \mathrm{AB}$ & $9.51 \mathrm{~B}$ & $11.65 \mathrm{~B}$ & $2.14 \mathrm{C}$ & $81.64 \mathrm{BC}$ \\
120 & $13.37 \mathrm{C}$ & $87.07 \mathrm{D}$ & $12.82 \mathrm{C}$ & $7.13 \mathrm{C}$ & $9.04 \mathrm{~B}$ & $21.91 \mathrm{C}$ & $78.92 \mathrm{D}$ \\
$\mathrm{LSD}(0.05)$ & $1.10^{*}$ & $0.45^{*}$ & $1.08^{*}$ & $2.14^{*}$ & $2.63^{*}$ & $0.49^{*}$ & $2.12^{*}$ \\
\hline
\end{tabular}

Multi-regression results showed that there are a regression among sucrose content, root yield and root water content with white and gross sugar yields (as below), sugar content having highest effect on sugar yield.

$$
\begin{array}{ll}
\mathrm{WSY}=0.098348 \times \mathrm{RY}+0.972667 \times \mathrm{SC}-0.030033 \times \mathrm{RWC} & \left(\mathrm{R}^{2}=0.9999\right) \\
\mathrm{GSY}=0.136747 \times \mathrm{RY}+0.717792 \times \mathrm{SC}-0.21579 \times \mathrm{RWC} & \left(\mathrm{R}^{2}=0.9999\right) \\
\mathrm{WSC}=-0.01783 \times \mathrm{RY}+1.357728 \times \mathrm{SC}-0.17606 \times \mathrm{RWC} & \left(\mathrm{R}^{2}=0.9999\right)
\end{array}
$$

Deficit irrigation also entails a number of constraints such as:

- crop response to drought stress should be studied carefully (Hsiao, 1973). Determining optimal timing of irrigation applications is particularly difficult for crops with crop water production functions in which maximal water productivity is found within a small optimum range of ET;

- irrigators should have unrestricted accress to irrigation water during sensitive growth stages. This is not always the case during periods of water storage (Zhang, 2003);

- a minimum quantity of irrigation water should always be available for application ( Zhang and Oweis, 1999; Kang et al., 2002; Geerts et al., 2008b). This is not always possible in extremely dry regions where irrigation water is scarce (Enfors and Gordon, 2008) 
The increases in water productivity under deficit irrigation can be attributed to the following reasons:

- water loss through evaporation is reduced;

- the negative effect of drought stress during specific phenological stages on biomass partitioning between reproductive and vegetative biomass(harvest index) is reduced (Fereres and Soriano, 2007; Reynolds and Tuberosa, 2008) due to increases the reproductive organs(Karam et al., 2009);

- water production for the net assimilations of biomass is increased as drought stress is mitigated or crops become more hardened. This effect due to conservative behavior of biomass growth in response to transpiration (Steduto et al., 2007);

- water productivity for the net assimilations of biomass is increased due to the synergy between irrigation and fertilization (Steduto and Albrizio, 2005);

- negative agronomic conditions are avoided during crop growth, such as pests, diseases, anaeobic conditions in the root zone due to water logging (Pereira et al., 2002 ; Geerts et al., 2008a).

In conclusion, the present study revealed that if water is limited and deficit irrigation is spread over growth season. The present findings were that deficit irrigation of sugar beet led to decrease in root and sugar yields and seasonal evapotranspiration. Water use efficiency values increased slightly with increase in water deficit. Irrigation at $60 \%$ of reference evapotranspiration (corresponding to $50 \%$ of soil moisture depletion) could be used for sugar beet grown in semi-arid regions such as Nubaria without decrease of root yield and white sugar yield. The findings in this study strongly recommend that up to $60 \%$ deficit irrigation of sugar beet would be advantage if the farmers target is to maximize root and white sugar yield. But if the target is to put more area into production under limited water supply, irrigation at $40 \%$ of reference evapotranspiration in sugar beet may be feasible. Also, this present results are good idea for scheduling irrigation with weather data instead of soil moisture data as confirmed with this study. Scheduling irrigation of sugar beet using weather data collected from nearby weather station is simple and accurate, in which requires the weather data and calculation of crop evapotranspiration using Penman-Monteith equation (Allen et al., 1998) or using any available computer software such as CROPWAT 8.0 (FAO, 2011) or AquaCrop 4.0 (Raes et al., 2012). 


\section{REFERENCES}

Ahadi, S.A. and M.M. Sobhani (2005). Effect of different irrigation amounts and potassium fertilizer rates on yield and quality of sugar beet and water efficiencies. J. Agric. Sci. miyane University, 21: 4687-4699

Allen, R. G., L. S. Pereira, D. Raes and M. Smith (1998). Crop evapotranspiration: guidelines for computing crop requirements. FAO Irrigation and Drainage Paper No. 56. FAO, Rome. Italy.

Bailey, R. J. (1990). Irrigation crops and their management. Ipswich Farming press. p. 192.

Bhador, M.A., M.A. Minoii and A.N. Alizadeh (2010). Effect of planting dates and NPK fertilization on growth and yield of sugar beet (Beta vulgaris L.). J. Agric. Sci. miyane University, 20: 2683-2689.

Bilgin, Y. (1992). Seker pancari verim ve kalitesini ekleyen bazi faktorler(in Turkis). Turkiye Seker Fabrikalari A. S. Seker Enstitusu Seminer Notlari. Ankara, pp 1-18.

Bosemark, N.P. (1993). Genetics and breeding. lin: Cooke, D.A. and R.K. Scott (ed) $1^{\text {st }}$ Cd. The Sugar Beet Crop. pp. 67-119. Chapman \& Hall, London.

Carter, M. R. and E. G. Gregorich (2008). Soil Sampling and Methods of Analysis, Second Edition. Canadian Society of Soil Science; Boca Raton, FL: CRC Press, 1264 pages.

Eaton, A.D. and M. A. H. Franson (2005). Standard Methods for the Examination of Water \& Wastewater. American Public Health Association, American Water Works Association, Water Environment Federation, American Public Health Association

Emara, T. K. (1996). Studies on the effect of some cultural practices on water parameters of sugar beet in North Delta Region. Ph. D. Thesis, Fac. of Agric., Mansoura Univ.

Enfors, E.I. and L. J. Gordon (2008). Dealing with drought: the challenge of using water system technologies to break dryland poverty traps: local evidence on vulnerabilities and adaptations to global environmental change. Global Environ. Change, 18: 607-616.

Fabeiro, C., M. Santa Olalla, R. Lopez and A. Dominguez (2003). Cultivation under controlled deficit irrigation condition in semi-arid climate. Agric. Water Manage., 62:215-227.

FAO (2011). CROPWAT, www.fao.org/nr/water/ informs databases cropwat.html (accessed on 2-1-2011).

Fereres, E. and M. A. Soriano (2007). Deficit irrigation for reducing agricultural water use. Special issue on "Integrated approaches to sustain and improve plant production under drought stress". J. Exp. Bot., 58, 147-159.

Geerts, S., D. Raes, M. Garcia, J. Vacher, R. Mamani, J. Mendoza, R. Huanca, B. Morales, R. Miranda, J. Cusicanqui and C. Taboada (2008a). Introducing deficit irrigation to stablize yields of quinoa (Chenopodium quinoa Willd.). Eur. J. Agron., 28: 427-436.

Geerts, S., D. Raes, M. Garcia, O. Condori, J. Mamani, R. Miranda, J. Cusicanqui, C. Taboada and J. Vacher (2008b). Could deficit irrigation be a sustainable practice for quinoa (Chenopodium quinoa Willd.) in the Southern Bolivian Altiplano? Agr. Water Manag., 95: 909-917. 
Harvey, C. W. and J. V. Dutton (1993). Root quality and processing in sugar beet crop: Science into practice. Edited by D. A. Cook and Scott. Published by Chapman and Hall, ISBN 0412-25132, pp 571-617.

Hassanli, A. M., S. Ahmadirad, and S. Beecham (2010). "Evaluation of the influence of irrigation methods and water quality on sugar beet yield and water use efficiency." Agric. Water Manage., 97(2), 357-362.

Hills, F. J., S. R. Winter, and D. W. Henderson (1990). "Sugarbeets." Agron. Monogr., 30, 795-810.

Hoffmann, C. M., T. Huijbregts, and N. S. Rudolf Jansen (2009). Impact of different environments in Europe on yield and quality of sugar beet genotypes. Eur. J. Agron., 30(1): 17-26.

Hsiao, T.C. (1973). Plant responses to water stress. Ann. Rev. Plant Physiol., 24: $519-570$.

Jahadakbar, M. R., H. R. Ebrahimian, J. Torabi, and J. Gohrai. (2003). Effect of water deficit on sugarbeet quality and quantity in Kabotarabad-Esfahan. J. Sugar Beet Res., 19(1), 81-100 (in Persian, with English abstract).

Kang, S., L. Zhang,Y. Liang, X. Hu, H. Cai, B. Gu (2002). Effects of limited irrigation on yield and water use efficiency of winter wheat in the Loess Plateau of China. Agr. Water Manag., 55:203-216.

Karam, F., R. Kabalan, J. Breidi, Y. Rouphael and T. Oweis (2009). Yield and water production functions of two durum wheat cultivars grown under different irrigation and nitrogen regimes. Agric. Water Manag., 96:603615.

Karimi A. and M. Naderi (2008). Different levels of irrigation and nitrogen effects on quantitative and qualitative yield and water use efficiency of Sugar beet. Science and agricultural industries (particularly water and soil), 22 (1): 235- 246.

Katerji, N., van Hoorn, J. W., Hamdy, A., Mastrorilli, M., and Mou Karzel, E. (1997). Osmotic adjustment of sugarbeets in response to soil salinity and its influence on stomatal conductance, growth and yield. Agric. Water Manage., 34(1), 57-69.

Kirda C. (2002) Deficit irrigation scheduling based on plant growth stages showing water stress tolerance, in $\mathrm{FAO}$, Deficit irrigation practices, Rome. 2002. 3-10.

Mahmoodi, R., Maralian, H. and Aghabarati, A. (2008). Effects of limited irrigation on root yield and quality of sugar beet (Beta vulgaris L.). African J. Biotech., 7(24): 4475-4478.

Maralian, M., A. Tobeh, S. Seif Amiri, R. Didar-Talesh Mikail and A. Aghabarati (2008). Effects of sowing date and limited irrigation on root yield and quality of sugar beet (Beta vulgaris L.). Asian J. Plant Sci., 7(3):298-303.

McGinnus, R. A. (1971). Sugar beet technology $2^{\text {nd }}$ ed. Sugar beet Development Foundation, Fort., Color, U.S.A.

Mirzaee M.R. and S. M. A., Rezvani (2007). Effects of water deficit on quality of sugar beet at different growth stages. Journal of Sugar Beet, 23: 29-42. (in Persian, abstract in English)

Mohamed, H. F. (2002). Chemical and technological studies on sugar beet. Ph. D. Thesis, Fac. Agric., Minia Univ., Egypt. 
Ober, E. S., M. Le Bloa, C. J. A. Clark, A. Royal, K. W. Jaggard and J. D. Pidgeon (2005). Evaluation of physiological traits as indirect selection criteria for drought tolerance in sugar beet. Field Crops Res., $91: 231-249$

Pereira, L.S., T. Oweis and A. Zairi (2002). Irrigation management under water scarcity. Agric. Water Manag., 57: 175-206.

Pidgeon, J. D., A. R. Werker, K.W Jaggard, G. M. Richter, D. H Lister and P. D. Jones (2001). Climatic impact on the productivity of sugar beet in Europe, 1961-1995. Agric. For. Meteorol., 109(1): 27-37.

Pollach, G., W. Hein and G. Rosner (1996). Definition der inneren Qua"litat von Zuckerruben-Definition of the internal quality of sugar beet. Zuckerind, 5: 332-344.

Raes, D., P. Steduto, Th. C. Hsiao and E. Fereres (2012). AquaCrop 4.0, Crop Water Productivity Model. Land and Water Division. FAO, Rome, Italy

Reynolds, M. and R. Tuberosa (2008). Translational research impacting on crop productivity in drought-prone environments. Curr. Opin. Plant Biol., 11: 171-179.

Salter, P. J., and J. E. Goode (1967). Crop responses to water at different stages of growth, Research Review No. 2, Commonwealth Agricultural Bureau, Farnham Royal, 246.

Shrestha, N., S. Geerts, D. Raes, S. Horemans, S. Soentjens, F. Maupas, P. Clouet (2010). Yield response of sugar beets to water stress under Western European conditions. Agric. Water Manage., 97(2): 346-350.

Snedecor, G.W. and W.G. Cochran (1991). Statistical Methods. Eight edition. lowa State Univ. Press, Ames. 503pp.

Statistix (2003). Statistix 8.2, Analytical Software for Window. Tallahassee, FL.

Steduto, P. and R. Albrizio (2005). Resource use-efficiency of field grown sunflower, sorghum, wheat and chickpea. II. Water use efficiency and comparison with radiation use efficiency. Agric. Forest Meteorol., 130: 269-281.

Steduto, P., T. C. Hsiao and E. Fereres (2007). On the conservative behavior of biomass water productivity. Irrig. Sci., 25: 189-207.

Tognetti, R., M. Palladino, A. Minnocci, S. Defline and A. Alvino (2003). The response of sugar beet to drip and low-pressure sprinkler irrigation in Souther Italy. Agric. Water Manag., 60:135-155.

Ucan, K. and C. Gencoglan (2004). The effect of water deficit on yield and yield components of sugar beet. Turk. J. Agric. For., 28:163-172

Wieninger, L. and $\mathbf{N}$. Kubadinow (1971). Beziehungen zwischen Rübenanalysen und technologischer Bevertung von Zuckerrüben. Assem. Commun. Int. Technol. Sucr. 14, 523-538.

Williams, L. J. and H. Abdi (2010). Fisher's Least Significant Difference (LSD) Test. In Neil Salkind (Ed.), Encyclopedia of Research Design, Thousand Oaks, CA: Sage.

Zhang, H. (2003). Improving water productivity through deficit irrigation: examples from Syria, the North China Plain and Oregon, USA. In: Kijne, J.W., Barker, R., Molden, D. (Eds.), Water Productivity in Agriculture: Limits and Opportunities for Improvement. International Water Management Institute, Colombo, Sri Lanka, pp. 301-309. 
Zhang, H., and T. Oweis (1999). Water-yield relations and optimal irrigation scheduling of wheat in the Mediterranean region. Agricultural Water Management, 38: 195-211.

$$
\text { الملخص العربي }
$$

استجابة محصول بنجر السكر لنقص الري تحت نظام الري بالتثقيط

جمال عبد الناصر خليل 1, خالد الطاهر بن عبد اللهُ2, عبد السلام ميرغني عثمان3.,

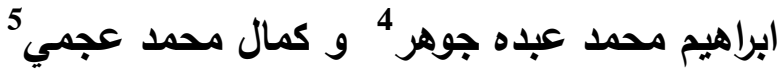

1 قسم الاراضي والكيمياء الزراعية - كلية الزراعة (سابا باثا) - جامعة الاسكندرية

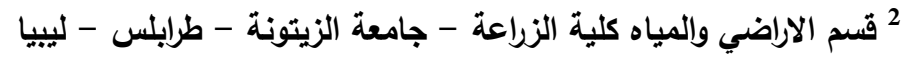

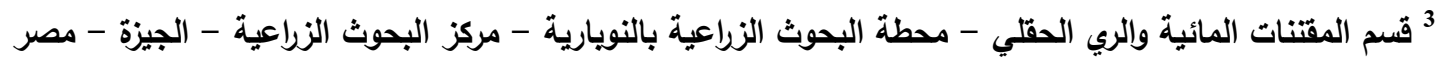

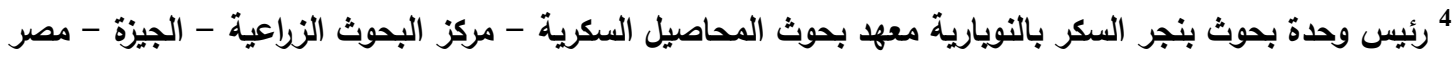

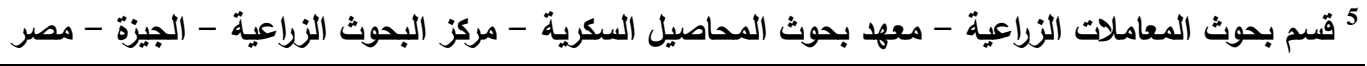

أجريت تجرية حقلية لمحصول بنجر السكر تحت نظام الري بالتنقيط فى الحقول البحثية لدحطة التجارب الزراعية بالنويارية - دصر خلال موسم النمو 2012/2011. الهاف من الداراسة الحالية هو تقييم تأثير نقص الري على انتاجية بنجر السكر وصفات جودة الجذور تحت نظام الري بالتنقيط. وقد تم زراعة بذور

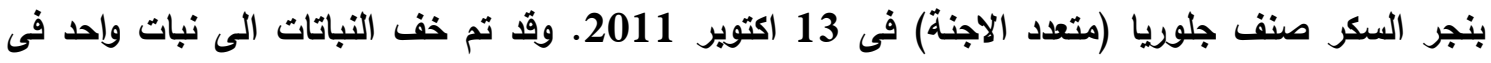
الجورة على مسافة 0.3 متر على طول الخط بابعاد بين الخطوط 0.5 متر فى عمر 4 اسابيع. بعد الانبات تم

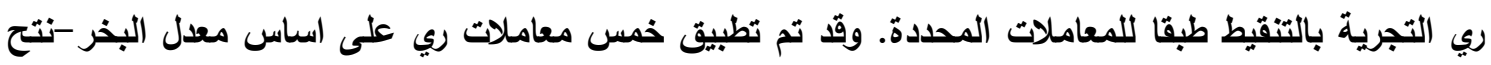

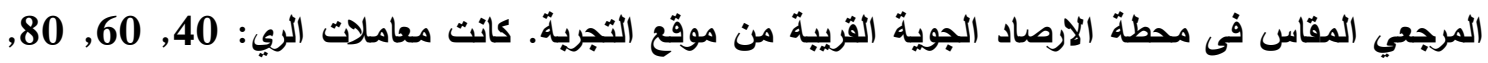
100 و 120\% من معدل البخر-نتح المرجعي ـ ثم تم تقير النمو الخضري , محصول الجذور لبنجر السكر الجرية وخصائص الجذور, جودة العصير والنقاوة, محتوى السكروز, محصول السكر النيكر الكلي والسكر الابيض. أثنارت

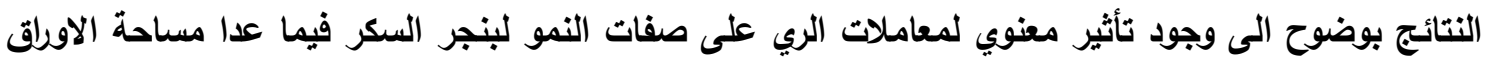

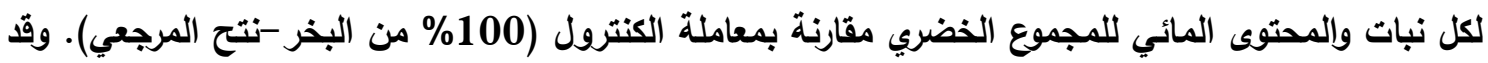

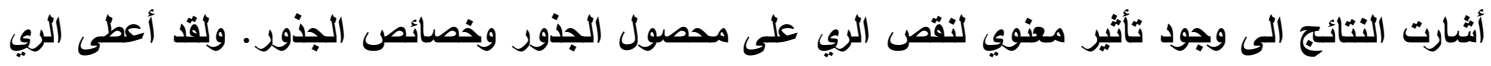

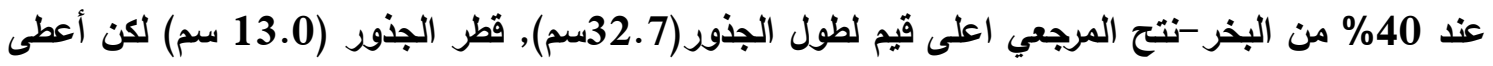

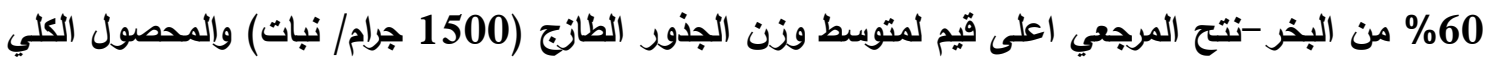

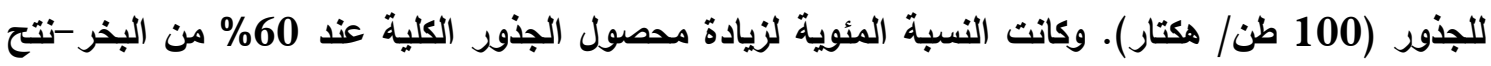

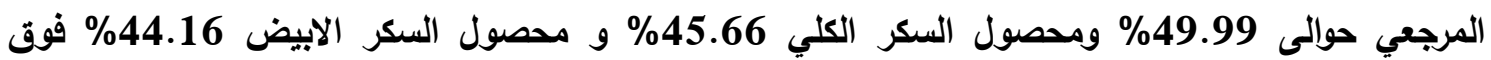
معاملة الكنترول (100\% من البخر-نتح المرجعي) ـ كما أثرت معاملات الري المختلفة معنويا على جودة 
العصير والنقاوة. فقد أعطى الري عند 60\% أعلى قيم للمواد الصلبة الكلية (23.00\%) بينما محصول السكر

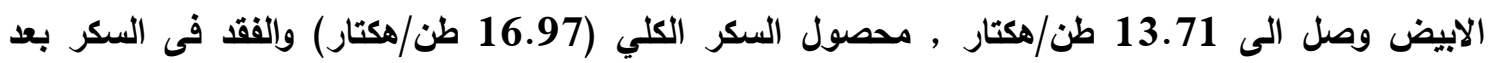

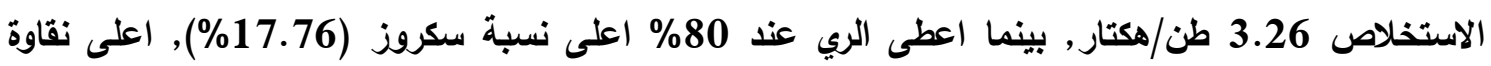
(90.66\%), اعلى محصول للسكر الابيض (14.94 طن/هكتار). وتعزى الزيادة فى محصول السكر الى زيادة

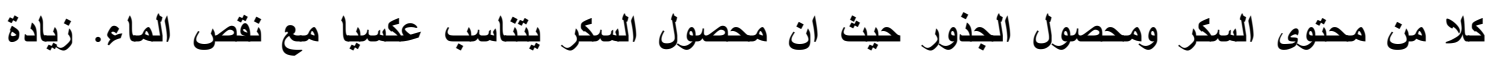

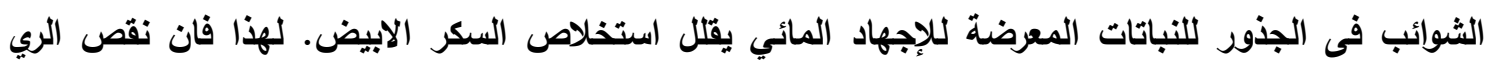
يمكن ان يحسن جودة بنجر السكر بتقليل الثوائب. ما تم التوصل اليه من الاراسة الحالية هو التوصية بمعدل

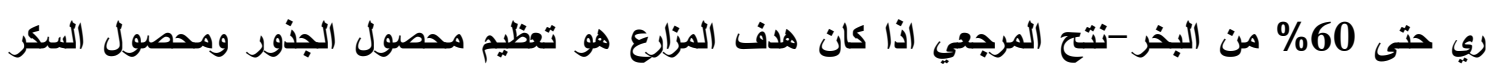
الابيض , لكن اذا كان هدف المزارع هو توفير مياه الري فان الري عند 40\% من لنف البخر نتح المرجعي يكون الافضل. 
